\title{
A Biological and Immunological Characterization of Schistosoma Japonicum Heat Shock Proteins 40 and $90 \alpha$
}

\author{
Zhipeng $\mathrm{Xu}{ }^{1,2} \oplus$, Minjun $\mathrm{Ji}^{2}$, Chen $\mathrm{Li}^{2}$, Xiaofeng $\mathrm{Du}{ }^{1}$, Wei $\mathrm{Hu}^{3}$, Donald Peter McManus ${ }^{1, * \mathbb{C}}$ \\ and Hong You ${ }^{1, *}$ \\ 1 Department of Immunology, Molecular Parasitology Laboratory, QIMR Berghofer Medical Research Institute, \\ Brisbane, QLD 4006, Australia; zhipengxu@njmu.edu.cn (Z.X.); Xiaofeng.Du@qimrberghofer.edu.au (X.D.) \\ 2 Department of Pathogen Biology, Nanjing Medical University, Nanjing 211166, China; \\ jiminjun@njmu.edu.cn (M.J.); lichen262628@163.com (C.L.) \\ 3 Collaborative Innovation Center for Genetics and Development, State Key Laboratory of Genetic \\ Engineering and Ministry of Education Key Laboratory of Contemporary Anthropology, School of Life \\ Sciences, Fudan University, Shanghai 200433, China; huw@fudan.edu.cn \\ * Correspondence: Don.McManus@qimrberghofer.edu.au (D.P.M.); Hong.You@qimrberghofer.edu.au (H.Y.); \\ Tel.: +61-07-3362-0401 (D.P.M.); +61-07-3362-0406 (H.Y.)
}

Received: 13 April 2020; Accepted: 3 June 2020; Published: 4 June 2020

\begin{abstract}
We characterized Schistosoma japonicum HSP40 (Sjp40) and HSP90 $\alpha$ (Sjp90 $\alpha$ ) in this study. Western blot analysis revealed both are present in soluble egg antigens and egg secretory proteins, implicating them in triggering the host immune response after secretion from eggs into host tissues. These observations were confirmed by immunolocalization showing both HSPs are located in the Reynolds' layer within mature eggs, suggesting they are secreted by miracidia and accumulate between the envelope and the eggshell. Both HSPs are present in the musculature and parenchyma of adult males and in the vitelline cells of females; only Sjp90 $\alpha$ is present on the tegument of adults. Sjp40 was able to enhance the expression of macrophages, dendritic cells, and eosinophilic cells in mouse liver non-parenchymal cells, whereas $\mathrm{rSjp} 90 \alpha$ only stimulated the expression of dendritic cells. T helper 1 (Th1), Th2, and Th17 responses were increased upon rSjp40 stimulation in vitro, but rSjp90 only stimulated an increased Th17 response. Sjp40 has an important role in reducing the expression of fibrogenic gene markers in hepatic stellate cells in vitro. Overall, these findings provide new information on HSPs in S. japonicum, improving our understanding of the pathological roles they play in their interaction with host immune cells.
\end{abstract}

Keywords: heat shock protein; Schistosoma japonicum; granuloma; Th1; Th2; Th17

\section{Introduction}

Schistosomiasis, caused by Schistosoma japonicum, is still a major public health problem that threatens many millions of people in the People's Republic of China [1,2]. The most serious pathology of this disease is caused by egg-induced hepatic granulomas and fibrosis in the livers and intestines, and this impacts on the hosts' quality of life and health status, resulting in severe morbidity and even mortality [3]. The pathological mechanism of hepatic granuloma formation is a soluble egg antigen (SEA) and egg secretory protein (ESP)-induced complex immune response that results in the accumulation of macrophages, eosinophils, dendritic cells, $\mathrm{CD}^{+}{ }^{+} \mathrm{T}$ cells and other immune cells [4]. Determining how these various immune cells are activated and recruited within the liver environment will provide new avenues to further understanding the process of immunopathology in schistosomiasis. 
Heat-shock proteins (HSPs) constitute the first line of protection for cells exposed to stressful conditions. They constitute a large group of molecular chaperones, which have been classified into several families, including HSP27, HSP40, HSP60, HSP70, HSP90, and HSP110, based on their molecular weight and sequence homology $[5,6]$. Secretion of HSPs from S. japonicum eggs has been shown to induce strong immunomodulatory effects, including immunostimulatory and immunosuppressive reactivities $[7,8]$. One of the most abundant egg proteins from S. japonicum is the egg-derived heat shock protein 40 (HSP40, Sjp40), which is able to restrain the activation of hepatic stellate cells (HSCs) through the STAT3/p53/p21 pathway [9]. Evidence showing Sjp40 is secreted into blood at the early stage of infection suggested a potential diagnostic application [10]. In addition, our previous work showed that Sjp40 significantly induced the expression of co-stimulatory molecules (CD40, CD80, and CD86) and MHCII on the surface of the macrophages [11], suggesting an important role in the activation of antigen-presenting cells. Notably, the peptides p6 (51-70), p25 (241-260), and p30 (291-310) derived from Sjp40 were able to inhibit allergic asthmatic reactions through inducing IFN- $\gamma$ production [12], indicating a novel form of immune protection through helminth infection.

Another abundant HSP derived from S. japonicum, named heat shock protein 90 (Sjp90), has been identified in adult worms [13]. Expression of Sjp90 was downregulated in UV-irradiated cercariae [14], probably due to the fact that the synthesis of heat shock proteins is inhibited by UV irradiation, which causes the parasite to release a variety of proteins with abnormal conformations [15]. In addition, proteome analysis showed Sjp90 $\alpha$ (the inducible cytosolic isoform of Hsp90) is present at high concentrations in the excretory/secretory (ES) proteins of adult S. japonicum, implying a central role in immunomodulation in the host-parasite relationship [7]. Furthermore, an immunoproteomic study showed tegumental expression of Sjp $90 \alpha$ and the HSP was predicted to interact with another tegument protein, a putative stress inducible protein 1 (STIP1, SJCHGC06661), which is highly antigenic and immunogenic and has six TPR domains and one STI1 domain [16]. However, the precise biological function of Sjp90 $\alpha$ in schistosomes and its potential immunological role in the definitive host remain unclear and need to be determined.

In this study, we cloned and characterized Sjp40 and Sjp90 $\alpha$ from S. japonicum. In addition, we used real-time PCR to measure the transcription levels of Sjp40 and Sjp90 $\alpha$ in different life cycle stages. Immunolocalization studies of Sjp40 and Sjp90 $\alpha$ were also undertaken in the eggs and worms. Furthermore, the potential effects of Sjp 40 and Sjp90 $\alpha$ on inflammatory cells, including macrophages, neutrophils, eosinophils, and T cells subsets, were analyzed by flow cytometry.

\section{Results}

\subsection{Determination of the Sequences and Tertiary Structures of Sjp40 and Sjp90 $\alpha$}

The sequence of S. japonicum HSP40 (Sjp40, ACL79582.1) comprises an open reading frame (ORF) of 1065 bp encoding 354 amino acids. Multiple alignments showed that Sjp40 shares 69\% amino acid sequence identity with Schistosoma mansoni HSP40 (Smp_302290), 64\% amino acid sequence identity with S. haematobium, and 31\% amino acid identity with Homo sapiens. S. japonicum HSP90 $\alpha$ (Sjp90 $\alpha$, CAX70123.1) comprises an open reading frame (ORF) of 780 bp encoding 259 amino acids. Sjp90 $\alpha$ shares $82 \%$ amino acid sequence identity with S. mansoni HSP90 (Smp_072330), 43\% amino acid sequence identity with $S$. haematobium, and $61 \%$ amino acid identity with Homo sapiens.

The three-dimensional (3D) structure of the two proteins was predicted by homology modeling using the online SWISS-MODEL tool [17]. For the Sjp40 structure, we found a protein homolog with an alignment length of 338 amino acids and corresponding PDB ID: 2bol.1.A, and this is shown in Figure 1a,b; the Sjp40 protein and this homolog showed $32.69 \%$ identity, with $88 \%$ coverage. Additionally, it presents a high global model quality estimation score (GMQE: 0.61) evaluated using the Ramachandran plot method, showing that $91.07 \%$ of residues fall in the favorable region and $8.93 \%$ in the additional allowed region. With the full length Sjp90 structure (Figure 1c,d), we selected the most homologous protein with an alignment length of 719 amino acids and corresponding PDB ID: 
5uls.1.A; this homolog showed $44.79 \%$ identity and $88 \%$ coverage with the Sjp90 protein. This template showed a high GMQE score (0.68) and a Ramachandran plot with $91.03 \%$ Sjp90 residues falling in the favorable region and $8.97 \%$ residues in the outlier region. The Ramachandran plot analysis show that the modeled 3D structures of Sjp40 and Sjp90 have acceptable stability ( $>90 \%$ in the most favored regions) following the rule of stereochemistry.

a

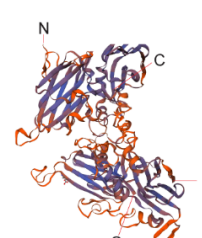

e

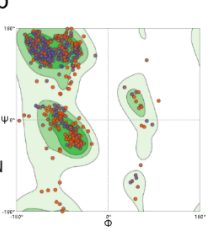

c

1 MS $\frac{\text { GTHQNHAVSTPVNREQCSFPRHRHELUQNVGKASKS GQLGSVVPYTED }}{\star} 50$

51 WPSSVSNWIESSLKSWDKEMERLRRGMFALLPMDRFMDGIPHDPLGMMHE 100

101 MDRHIEELQNGMGLSAVAPLGSTSDYLKDAYEVGDDGKVHFKVRFDAQGF 150

151 APEDINVTSSDNRVTVHAKKETTTGGKKCSHEFCRMIQLPKSIENNQLKC 200

201 RLTDDGVLMLEAPVKVGENKSLTMNESGQVGIQPKSASQIQAVPASQALT 250

$251 \frac{\text { VKGCQGLTVLDDGAGGKKLHVEVQLDPVYRPEDLCVNIDSNRVVVSGRHY }}{\mathbf{\Lambda}} 300$

301 KOKTDARRKSSSFAEFSQSYSIPETVDPLTVSAQVVDNMLVVEAPMMKOH 350

351 EIAH 354

* N-myristoylation site $\quad \Delta$ Protein kinase $\mathrm{C}$ phosphorylation site - N-glycosylation site $\quad$ Casein kinase II phosphorylation site - cAMP- and CGMP-dependent protein kinase phosphorylation site

$\square$ Amidation site

f

$$
\begin{aligned}
& 1 \text { MPEPMSTEPQPETEAFQAEIAQLMSLIINTEYSNKEIFLRELIS } \frac{\text { NA]SD }}{0} 50
\end{aligned}
$$

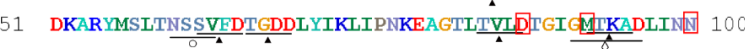

$$
\begin{aligned}
& 101 \text { LGTIASSG SKAFMEALQVGADISMI GQFGVGFYSAYLVADRVQVVTKNNND } 150
\end{aligned}
$$

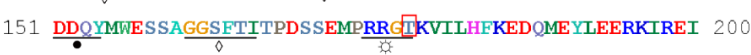

$$
\begin{aligned}
& 201 \text { VKKHS QFINYPIKLVVDKERTKEVSDDEAEKEETKNESEEAEDKPKVEDL } 250 \\
& 251 \text { DEDEEEDNKDKKKKKKVTEKYTEEEQLNKLRPLWTRNPEDITAEEYGEFY } 300 \\
& 301 \text { KSLNNDWEDHLAVKHF SVEGQLEFRALLFVPKRAPFDMFEGRKKRNNIKL } 350 \\
& 351 \text { YVRRVETMDNCEELIPEYLSEVRGVVDSEDLPLNISREMLQQSNVLKMIR } 400 \\
& 401 \text { KNLVKKCIELFEEIVEDKENYKKF YEQE SKNIKLGIHEDSVNRKKLAELL } 450 \\
& 451 \text { RYQSTASGDEMT } \frac{\text { SLKEYVSRMKPEQKDIYYITGETKQAVANSPETEKLTQ }}{*} 500 \\
& 501 \text { RGFEVLYMLDPIDEYSVTHLRE YDGKKLVCVTKDGLQLPENEEDKKKFEE } 550 \\
& 551 \text { LKASYEPLCKNVQEILGKSVEKVSISNRLTSSPCCVVISEFGWSANMERI } 600
\end{aligned}
$$

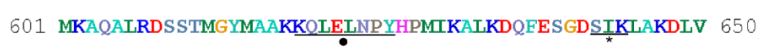

$$
\begin{aligned}
& 651 \text { QLLYDTALLSSGESLTDPKIHAKSIHHLVCMCLDIPDEEMKGKCVAADNG } 700 \\
& 701 \text { PTVAPPAEAGDDAGMEEVD } 719 \\
& \text { * Protein kinase C phosphorylation site \. Casein kinase Il phosphorylation site } \\
& \begin{array}{lr}
\text { - N-glycosylation site } & 0 \mathrm{~N} \text {-myristoylation site } \\
\text { - Tyrosine kinase phosphorylation site } & \square \text { Amidation site }
\end{array} \\
& \text { CAMP-and CGMP-dependent protein kinase phosphorylation site } \\
& \square \text { ATP-binding site }
\end{aligned}
$$

Figure 1. Predicted 3D structure and motifs of Sjp40 and Sjp90 $\alpha$. Homology modeling was performed using the Swiss-Model Server and the predicted 3D structure of homo-dimer Sjp40 (a) and homo-dimer Sjp90 (c) are shown. Model quality was evaluated using the Ramachandran plot method and the results represent the acceptable stability of the 3D structure of Sjp40 (b) and Sjp90 (d). (e) Sjp40 motifs: *: N-myristoylation site; $\mathbf{\Lambda}$ : protein kinase C phosphorylation site; $\diamond$ : casein kinase II phosphorylation site; $\bigcirc$ : N-glycosylation site; $\bullet$ : cAMP- and cGMP-dependent protein kinase phosphorylation site; and $\square$ : amidation site. (f) Sjp90 motifs: *: protein kinase C phosphorylation site; $\mathbf{\Delta}$ : casein kinase II phosphorylation site; $\diamond$ : N-myristoylation site; $\bullet$ : tyrosine kinase phosphorylation site; $\square$ : amidation site; : cAMP- and cGMP-dependent protein kinase phosphorylation site; and $\square$ : ATP-binding site. 
Conserved functional domains of Sjp40 and Sjp90 $\alpha$ were identified by comparing sequence identity with HSPs of other species (Figures S1 and S2), including S. mansoni, Homo sapiens, and Mus musculus. Using the Scan Prosite of ExPASy analysis tools (https://prosite.expasy.org), 23 motif hits (by six distinct patterns) were identified in Sjp40 (Figure 1e) including (1) four N-myristoylation sites, which can acylate eukaryotic proteins and target proteins to cellular membranes [18]; (2) four protein kinase $C$ phosphorylation sites, which exhibit a preference for the phosphorylation of serine or threonine residues found close to a C-terminal basic residue [19]; (3) six casein kinase II phosphorylation sites, whose activity is independent of cyclic nucleotides and calcium [20]; (4) three N-glycosylation sites, which relate to tyrosinase activity by helping protein folding [21]; (5) four cAMP- and cGMP-dependent protein kinase phosphorylation sites that contribute to the phosphorylation of serine or threonine residues [22,23]; and (6) two amidation sites. In the full length amino acid sequence of Sjp90 $\alpha$, there were 38 hits (by eight distinct patterns) presented (Figure 1f) including (1) seven protein kinase C phosphorylation sites; (2) twelve casein kinase II phosphorylation sites; (3) four N-glycosylation sites; (4) six N-myristoylation site; (5) four tyrosine kinase phosphorylation sites, which modulate enzymatic activity and recruit downstream insulin receptor substrate (IRS) proteins [24]; (6) three cAMPand cGMP-dependent protein kinase phosphorylation sites; (7) two amidation sites; (8) a MEEVD motif, which is reported to provide the binding site for interaction with the tetratricopeptide repeat (TPR)-domain (mediate protein-protein interaction) containing co-chaperones [25,26]; and (9) 19 ATP-binding sites, which are extremely conserved as these sites are present in murine heat shock protein HSP90 (NP_032328.2) and indicate that Sjp90 $\alpha$ has ATPase activity.

\subsection{Stage-Specific mRNA Expression of Sjp40 and Sjp90 $\alpha$}

To determine the transcription levels of Sjp40 and Sjp90 $\alpha$ in different life cycle stages of S. japonicum, RT-PCR was performed and normalized with the house keeping gene PSMD4 (26S proteasome non-ATPase regulatory subunit 4), which has been validated as a standard reference gene in transcriptomic analysis of S. japonicum in a number of studies [27-30]. The analysis revealed that both Sjp40 and Sjp90 $\alpha$ were expressed in schistosomula, adult worms, and eggs of S. japonicum (Figure 2a,b) with the lowest expression level recorded in cercariae. The transcription level of Sjp40 was strikingly higher in eggs than other stages $\left(F_{(4,29)}=47.47\right.$, Least Significant Difference (LSD) post-hoc test: $p<0.0001$ ) (Figure 2a), whereas Sjp90 $\alpha$ expression was elevated in adult males with transcription levels in eggs, schistosomulum, and adult females being similar $\left(F_{(4,29)}=124.1\right.$, all LSD: $\left.p<0.0001\right)$ (Figure 2b). 
a

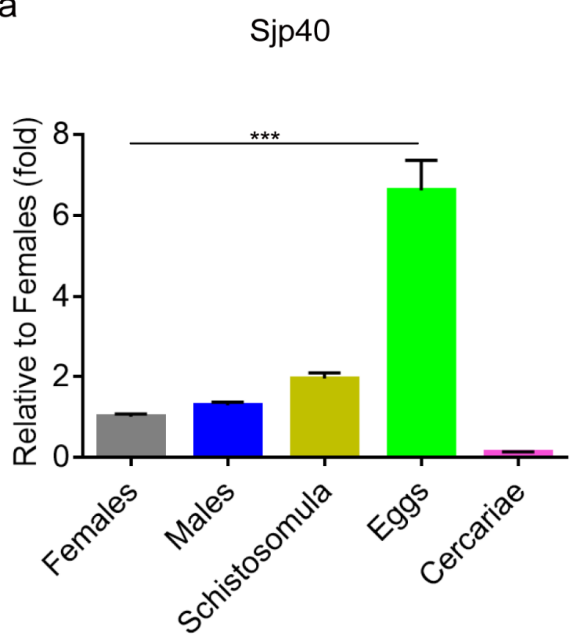

b

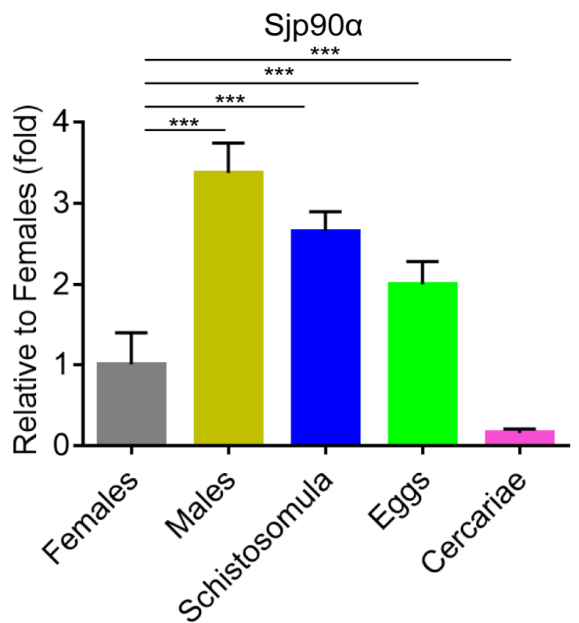

Figure 2. Expression levels of Sjp40 and Sjp90 $\alpha$ in different life cycle developmental stages of S. japonicum. RT-PCR analysis was performed to measure the transcription of Sjp40 (a) and Sjp90 $\alpha$ (b) in female and male adult worms, schistosomula, eggs and cercariae (S. japonicum PSMD4 was used as house-keeping gene); then the transcription levels of Sjp40 and Sjp90 $\alpha$ were normalized to those of female worms, which had certain expressed CT values for comparison. Data are represented as the mean of two independent experiments with SEM. Multiple comparisons were performed by one-way ANOVA, followed by Least Significant Difference (LSD) post hoc test for comparisons between two groups ${ }^{* *} p<0.001$ significant differences compared with the adult female stage.

\subsection{Distribution of Sjp40 and Sjp90a in S. Japonicum Eggs}

Immunolocalization of eggs trapped in infected mouse livers using either HRP labeling or immunofluorescence showed that native Sjp40 and Sjp90 $\alpha$ were expressed inside immature eggs (Figure 3a), with both HSPs mainly localized to neural mass (NM) cells (one single large cell with numerous peripheral nuclei) and in the epidermis (EPI) cells of the intra-ovular miracidium within mature eggs (Figure 3b). Furthermore, fluorescence signaling of Sjp40 and Sjp90 $\alpha$ was detected in the Reynolds' layer (Figure 3b), which only appears between the envelope and the eggshell in the mature egg and may represent its accumulated secretions [31].

To determine whether Sjp40 and Sjp90 $\alpha$ could be secreted by the S. japonicum eggs, Western blot analysis was undertaken using mouse anti-rSjp 40 or rSjp90 $\alpha$ serum to probe egg secreted proteins (ESP) and soluble egg antigens (SEA) from purified eggs (Figure S3). As shown in Figure 3c, native Sjp40 was recognized by anti-rSjp40 serum both in SEA and ESP at the predicted size of $39.2 \mathrm{kDa}$. A clear band at approximately $100 \mathrm{kDa}$ was recognized by anti-rSj90 $\alpha$ both in SEA and ESP (Figure 3d); this was probably due to post-translational modification of the full length Sjp90, due to glycosylation and/or phosphorylation [32], but this needs to be further investigated. Together, these results indicate that Sjp40 and Sjp90 $\alpha$ are secreted by the mature eggs of S. japonicum. 


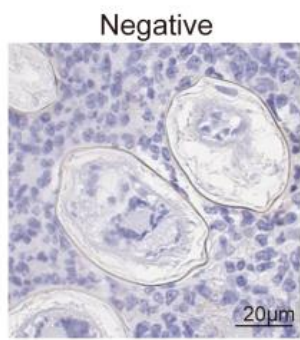

b
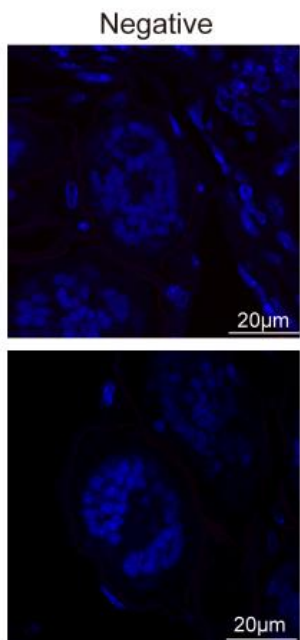
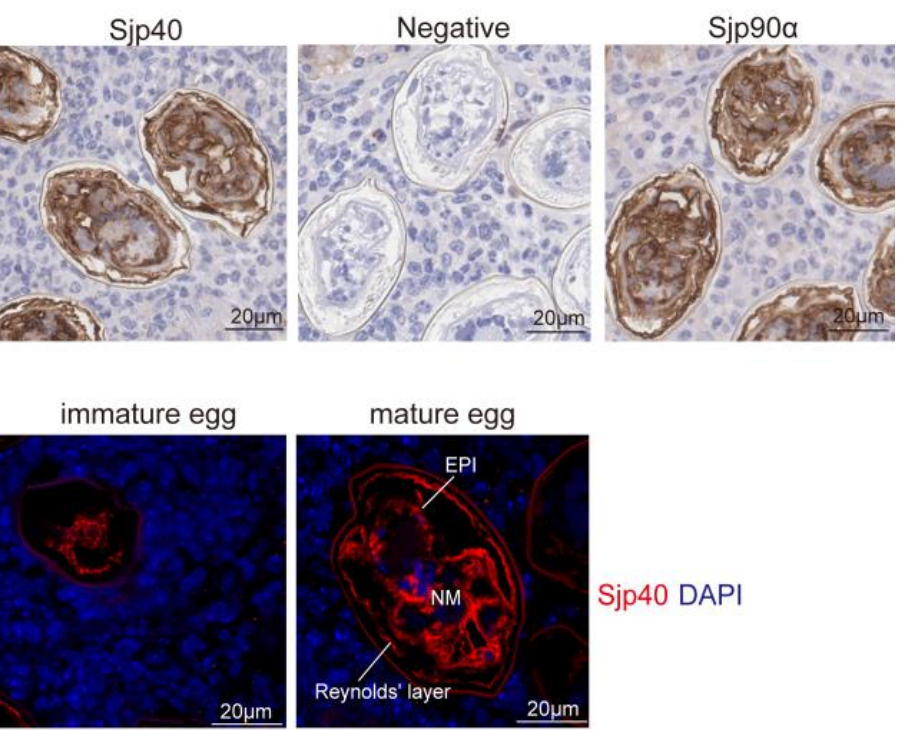

Sjp40 DAPI
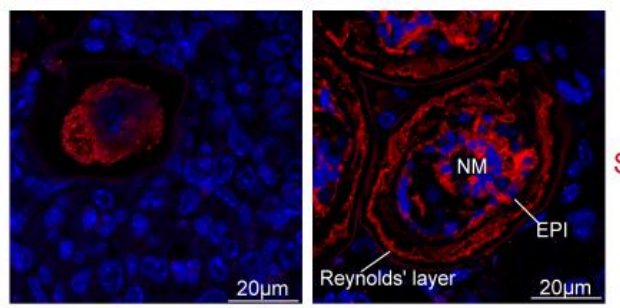

Sjp90a DAPI

d

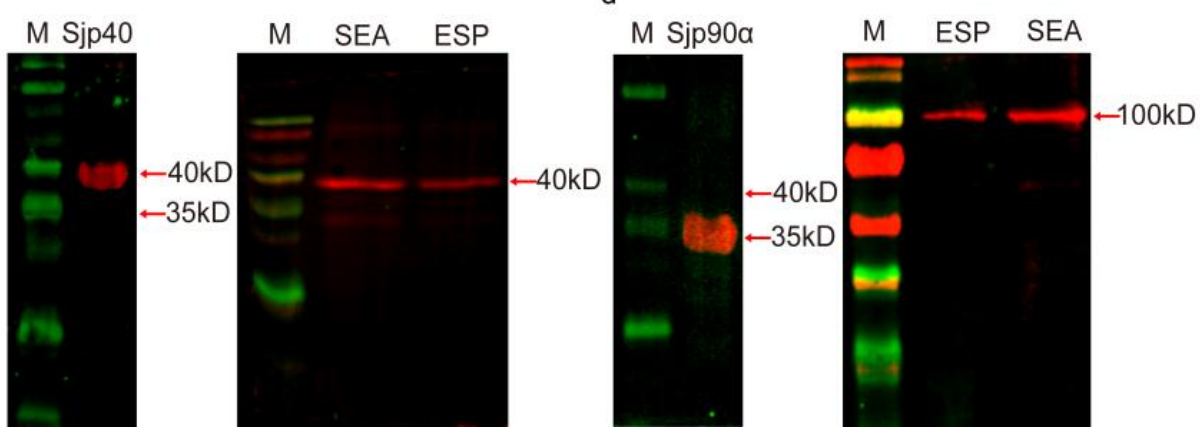

Figure 3. Native Sjp40 and Sjp90 $\alpha$ identified in eggs and egg secreted proteins (ESP) of S. japonicum. Immunolocalization of Sjp40 and Sjp90 $\alpha$ in eggs trapped in infected mouse liver probed with mouse anti-rSjp40 and anti-rSjp90 antibodies, respectively. Sections of livers from mice infected with S. japonicum were incubated with naïve control mouse serum (negative control) and mouse anti-rSjp40 or anti-rSjp90 $\alpha$ antiserum, and subsequently with horseradish peroxidase (HRP)-conjugated secondary antibody (a) or Alexa-Fluor 647-conjugated secondary antibody (b). DAPI stained nuclei are blue. A section of schistosome eggs in a developing granuloma shows SjP40 or Sjp90 staining (brown in HRP labelling and red in Alexa-Fluor 647) in eggs. NM-neural mass; EPI—epidermal cells. Scale-bars: $20 \mu \mathrm{m}$. (c,d) Western blotting was used to detect recombinant Sjp40 (c, left lane) and Sjp90 $\alpha$ (d, left lane). Anti-rSjp40 (c, right lane) and anti-rSjp90 (d, right lane) were used to probe protein extracts of the soluble egg antigen (SEA) and egg secreted protein (ESP).

\subsection{Immunolocalization of Sjp40 and Sjp90 $\alpha$ in Adult S. Japonicum}

We determined the distribution of Sjp40 and Sjp90 $\alpha$ in male and female worms using both HRP labeling and immunofluorescence; the results showed that native Sjp40 is not only expressed in the underlying musculature but is also present throughout the parenchyma of males and the vitelline cells of females (Figure 4 and Figure S4A). Sjp90 $\alpha$ was expressed throughout the parenchyma and testis 
of males and vitelline cells of female; In addition, the Sjp90 $\alpha$ is present in the tegument of male and female worms (Figure 4 and Figure S4B).

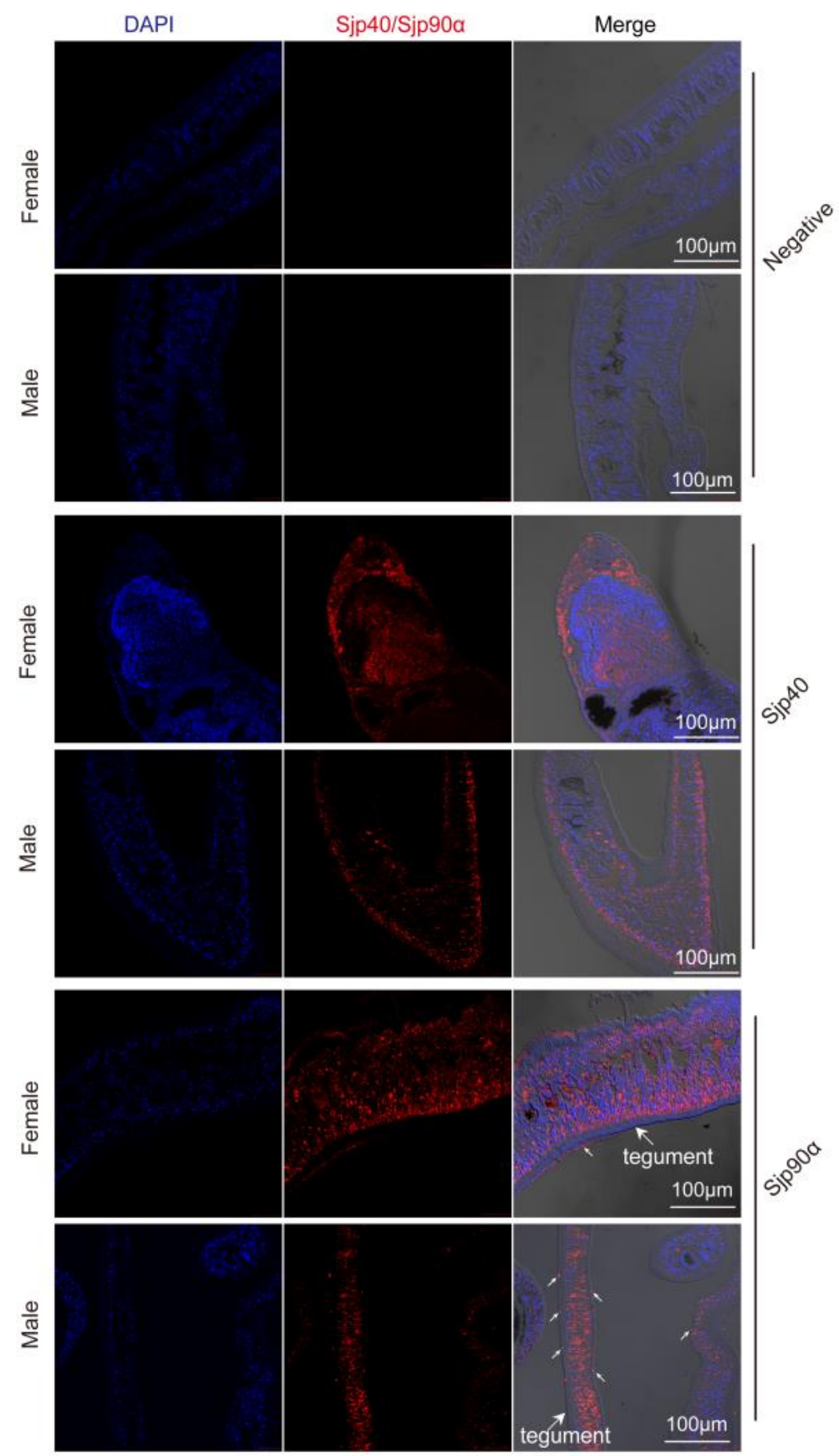

Figure 4. Distribution of Sjp40 and Sjp90 $\alpha$ in adult S. japonicum. Immunolocalization of Sjp40 and Sjp90 $\alpha$ in the worms of S. japonicum. Adult male and female worm sections were labelled with mouse anti-rSjp40 and anti-rSjp90 $\alpha$ antibody coupled with Alexa-Fluor 647 goat anti-mouse IgG (red), DAPI was used to stain for nuclei and the samples were analyzed using a Zeiss 780 NLO laser. Negative control sections of the worm were incubated with normal mouse serum. Scale-bars: $100 \mu \mathrm{m}$. White arrows indicate the Sjp90 $\alpha$ expressed in the tegument of worms. 


\subsection{Effect of $r S j p 40$ and $r S j p 90 \alpha$ on Hepatic Immune Cells}

To better understand the immune roles of the egg-secreted Sjp40 and Sjp90 $\alpha$ in mouse liver, we in vitro treated hepatic mononuclear cells derived from S. japonicum-infected mice with $\mathrm{rSjp} 40$ and $\mathrm{rSjp} 90$. FACS analysis indicated significantly increased proportions of macrophages (F4/80 $\left.{ }^{+} \mathrm{CD} 11 \mathrm{c}^{-}\right)\left(F_{(3,16)}=4.705\right.$, LSD: $\left.p=0.0136\right)$ (Figure 5a,b), dendritic cells $\left(\mathrm{F} 4 / 80^{-} \mathrm{CD} 11 \mathrm{c}^{+}\right)\left(F_{(3,16)}=6.027, \mathrm{LSD}: p=0.0113\right)$ (Figure 5a,c), and eosinophilic cells (Siglecf $^{+} \mathrm{CD} 1 \mathrm{c}^{-}$) $\left(F_{(3,16)}=30.25\right.$, LSD: $\left.p<0.0001\right)$ (Figure 5a,d) were detected in these hepatic immune cells after incubation with $\mathrm{rSip} 40$. Stimulation with $\mathrm{rSjp} 90 \alpha$ primarily enhanced the response of dendritic cells $\left(\mathrm{F} 4 / 80^{-} \mathrm{CD} 11 \mathrm{c}^{+}\right)\left(F_{(3,16)}=6.027\right.$, LSD: $\left.p=0.0166\right)$ (Figure 5a,c). However, neither rSjp40 or rSjp90 $\alpha$ had any effect on granulocytes $\left(\mathrm{Gr} 1^{+} \mathrm{CD} 11 \mathrm{c}^{-}\right)$(Figure 5e).

\section{a}

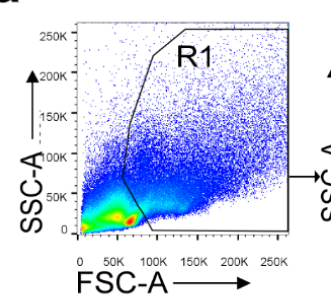

b

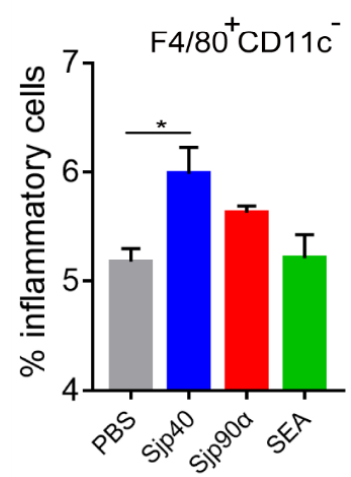

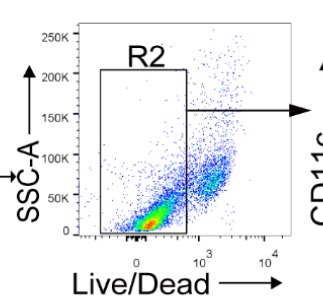

C

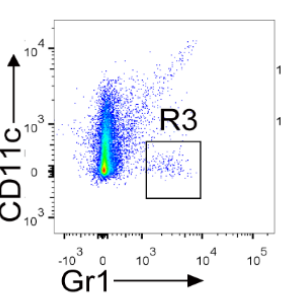

d

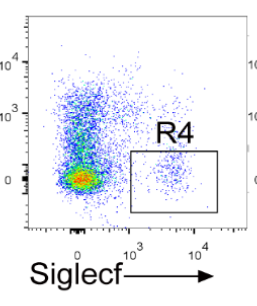

\section{e}

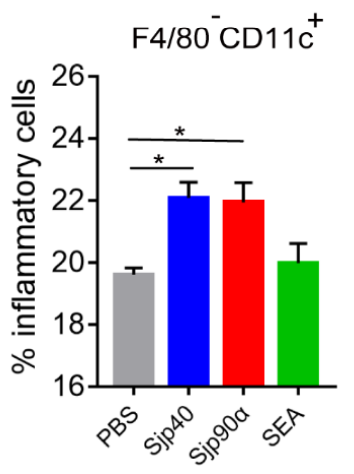

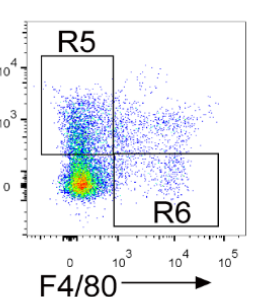

$\mathrm{F} 4 / 80$

Figure 5. Sjp40 and Sjp90 $\alpha$ induce hepatic inflammatory responses. Hepatic immune cells $\left(2 \times 10^{6}\right)$ from S. japonicum-infected mice were stimulated with $\mathrm{rSjp} 40(20 \mu \mathrm{g} / \mathrm{mL}), \mathrm{rSjp} 90 \alpha(20 \mu \mathrm{g} / \mathrm{mL})$ and SEA $(20 \mu \mathrm{g} / \mathrm{mL})$ for $48 \mathrm{~h}$, respectively, then the proportions of hepatic immune cell subsets were investigated. Gating strategy (a) and the percentages of macrophages $\left(\mathrm{F} 4 / 80^{+} \mathrm{CD}_{11 \mathrm{c}^{-}}\right)(\mathbf{b})$, dendric cells $\left(\mathrm{F} 4 / 80^{-} \mathrm{CD} 11 \mathrm{c}^{+}\right)(\mathbf{c})$, eosinophilic cells $\left(\right.$ Siglecf $\left.{ }^{+} \mathrm{CD} 11 \mathrm{c}^{-}\right)(\mathbf{d})$, and granulocytes $\left(\mathrm{Gr} 1^{+} \mathrm{CD} 11 \mathrm{c}^{-}\right)(\mathbf{e})$ in inflammatory cells were analyzed by FACS. Data are expressed as the mean $\pm \operatorname{SEM}(n=5$ each group), $* * * p<0.001, * p<0.05$ (ANOVA/LSD).

$\mathrm{CD}^{+}$Th cells play essential roles in the initiation and regulation of the hepatic immune response and pathology during schistosome infection [3]. We found in vitro treatment of hepatic mononuclear cells from $S$. japonicum-infected mice with $\mathrm{rSjp} 40$ and $\mathrm{rSjp} 90 \alpha$ resulted in an increase in the proportion of $\mathrm{CD}^{+}$cells $\left(\mathrm{CD} 90.2^{+} \mathrm{CD}^{+}\right)\left(F_{(3,12)}=115.0\right.$, both LSD: $\left.p<0.0001\right)$ (Figure 6a,b); these cells orchestrate the development of granulomas in schistosomiasis [3]. In addition, treatment of hepatic mononuclear cells with rSjp40 also induced significantly increased proportions of Th1 cells (CD90.2 $\left.{ }^{+} \mathrm{CD}^{+} \mathrm{IFN}-\gamma^{+}\right)$ $\left(F_{(3,12)}=3.551\right.$, LSD: $\left.p=0.0405\right)$, Th2 cells $\left(\mathrm{CD} 90.2^{+} \mathrm{CD} 4^{+} \mathrm{IL}-4^{+}\right)\left(F_{(3,12)}=5.226\right.$, LSD: $\left.p=0.0159\right)$, Th17 cells $\left(\mathrm{CD} 90.2^{+} \mathrm{CD}^{+} \mathrm{IL}^{-17^{+}}\right)\left(F_{(3,12)}=6.623\right.$, LSD: $\left.p=0.0031\right)$, but not Treg cells $\left(\mathrm{CD} 90.2^{+} \mathrm{CD}^{+} \mathrm{Foxp}^{+}\right)$, whereas rSjp90 $\alpha$ predominantly induced the expression of Th17 cells $\left(F_{(3,12)}=6.623\right.$, LSD: $\left.p=0.0168\right)$, but not Th1/2 or Tregs (Figure 6a-f). However, cells treated with SEA, a complex mixture of egg components, and a well-known stimulator of Th2 responses, generated enhanced numbers of $\mathrm{CD} 4^{+}$cells $\left(F_{(3,12)}=115.0\right.$, LSD: $\left.p<0.0001\right)$, Th2 $\left(F_{(3,12)}=5.226\right.$, LSD: $\left.p=0.0118\right)$, and Treg cells $\left(F_{(3,12)}=4.373\right.$, LSD: 
$p=0.0171$ ) (Figure 6a-f). Of note, we also observed multiple intracellular cytokines in CD90.2- $\mathrm{CD}^{+}$ cells (Figure 6e-i), which have been reported to be unusually expressed in the germinal centers of spleen and lymph nodes [33]. The treatment of hepatic mononuclear cells from $S$. japonicum-infected mice with $\mathrm{rSjp} 40$ and $\mathrm{rSjp} 90 \alpha$ resulted in an increase in the proportion of $\mathrm{CD} 90.2^{-} \mathrm{CD} 4^{+}$cells $\left(F_{(3,12)}=29.35\right.$, both LSD: $p<0.0001$ ) (Figure 6g). In addition, the treatment of hepatic mononuclear cells with rSjp40 also significantly stimulated responses of CD90.2- CD4 $4^{+} \mathrm{IL}-4^{+}\left(F_{(3,12)}=4.489\right.$, LSD: $\left.p=0.0159\right)$ and CD $90.2^{-} \mathrm{CD} 4^{+} \mathrm{IL}-17^{+}$cells $\left(F_{(3,12)}=4.089\right.$, LSD: $\left.p=0.0349\right)$ (Figure $\left.6 \mathrm{~h}, \mathrm{j}\right)$, whereas $\mathrm{rSjp} 90 \alpha$ predominantly induced the expression of CD90.2- ${ }^{-} \mathrm{CD} 4^{+} \mathrm{IFN}-\gamma^{+}\left(F_{(3,12)}=3.551\right.$, LSD: $\left.p=0.0272\right)$ and CD90.2- ${ }^{-} 4^{+}$ IL-17 ${ }^{+}$cells $\left(F_{(3,12)}=4.089\right.$, LSD: $\left.p=0.0223\right)$ (Figure $\left.6 \mathrm{i}, \mathrm{j}\right)$.

\section{a}

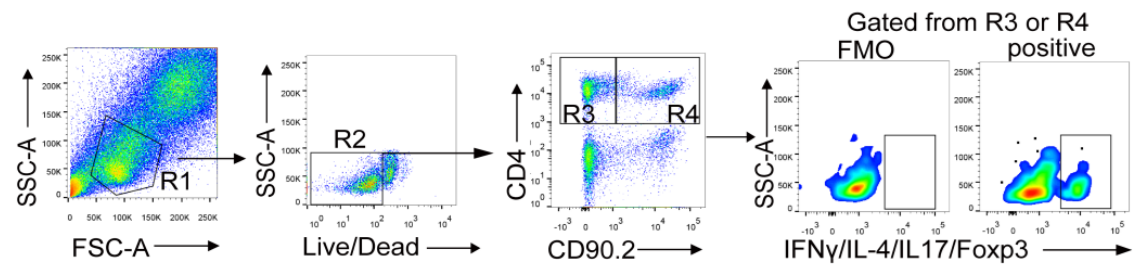

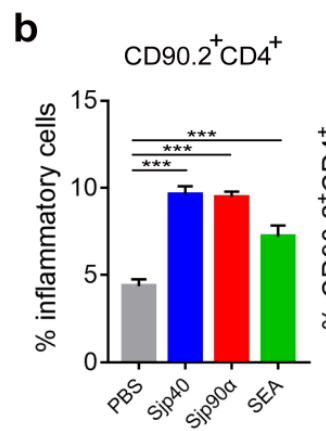

g

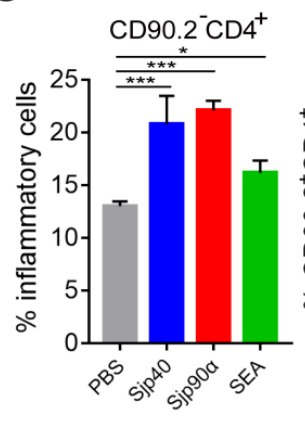

C $\mathrm{CD} 90.2^{+} \mathrm{CD}^{+} \mathrm{IFN} \mathrm{FN}^{+}$

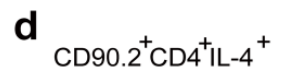

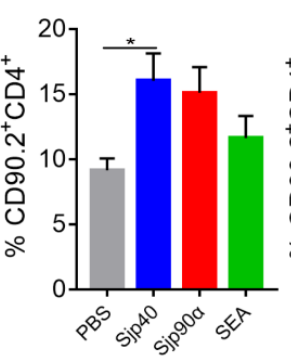

h

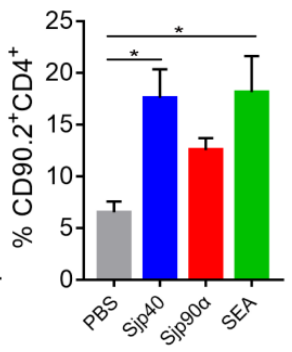

i

${ }_{\mathrm{CD} 90.2^{+} \mathrm{CD} 4^{+} \mathrm{IL}-17^{+}} \mathbf{f}$ $\mathrm{CD} 90.2^{+} \mathrm{CD} 4^{+} \mathrm{Foxp} 3$

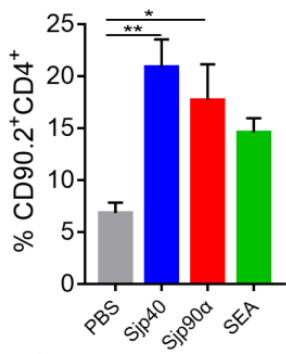

j $\mathrm{CD} 90.2^{-} \mathrm{CD}^{+} \mathrm{IL}-17^{+}$

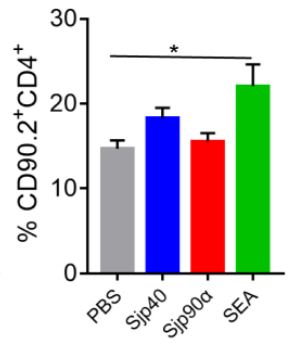

k

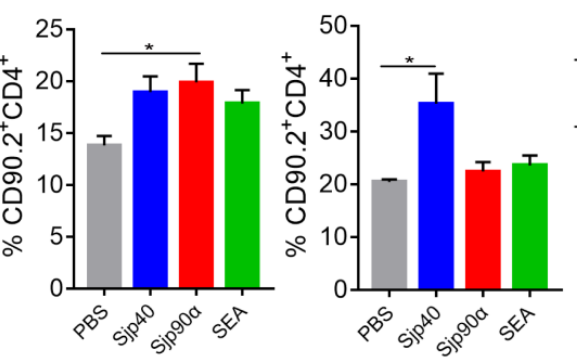

$\mathrm{CD} 90.2^{-} \mathrm{CD}^{+} \mathrm{Foxp}^{+}$

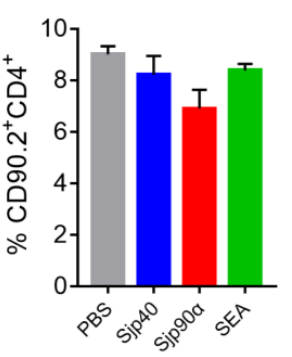

Figure 6. Mouse liver $\mathrm{CD}^{+} \mathrm{T}$ cells response induced by $\mathrm{rSjp} 40$ and $\mathrm{rSjp} 90 \alpha$. Hepatic immune cells $\left(2 \times 10^{6}\right)$ from $S$. japonicum-infected mice were treated with $\mathrm{rSjp} 40(20 \mu \mathrm{g} / \mathrm{mL}), \mathrm{rSjp} 90 \alpha$ $(20 \mu \mathrm{g} / \mathrm{mL})$ and SEA $(20 \mu \mathrm{g} / \mathrm{mL})$ following PMA/ionomycin stimulation. The gating strategy (a) and proportion of $\mathrm{CD} 4^{+}$cells $\left(\mathrm{CD} 90.2^{+} \mathrm{CD} 4^{+}\right)(\mathbf{b})$, Th1 cells $\left(\mathrm{CD} 90.2^{+} \mathrm{CD} 4^{+} \mathrm{IFN}-\gamma^{+}\right)(\mathbf{c})$, Th2 cells $\left(\mathrm{CD} 90.2^{+} \mathrm{CD} 4^{+} \mathrm{IL}-4^{+}\right)(\mathrm{d})$, Th17 cells $\left(\mathrm{CD} 90.2^{+} \mathrm{CD} 4^{+} \mathrm{IL}-17^{+}\right)(\mathrm{e})$, Treg cells $\left(\mathrm{CD} 90.2^{+} \mathrm{CD} 4^{+} \mathrm{Foxp} 3^{+}\right)$ $(\mathbf{f}), \mathrm{CD} 90.2^{-} \mathrm{CD}^{+}(\mathrm{g}), \mathrm{CD} 90.2^{-} \mathrm{CD} 4^{+} \mathrm{IFN}-\gamma^{+}(\mathrm{h}), \mathrm{CD} 90.2^{-} \mathrm{CD} 4^{+} \mathrm{IL}-4^{+}(\mathbf{i}), \mathrm{CD} 90.2^{-} \mathrm{CD} 4^{+} \mathrm{IL}-17^{+}(\mathrm{j})$, and $\mathrm{CD} 90.2^{-} \mathrm{CD} 4^{+} \mathrm{Foxp} 3^{+}$cells $(\mathbf{k})$ in lymphocytes were analyzed by FACS. Data are shown as the mean $\pm \operatorname{SEM}\left(n=4\right.$ each group), ${ }^{* * *} p<0.001,{ }^{* *} p<0.01,{ }^{*} p<0.05$ (ANOVA/LSD).

\subsection{Effect of rSjp40 and rSjp90a on Hepatic Stellate Cells}

We investigated the interaction between Sjp40 and Sjp90 $\alpha$ with hepatic stellate cells (HSCs), which are the key cellular players in the development of hepatic fibrosis, by stimulating LX-2 cells with rSjp40 and rSjp90 $\alpha$. As noted in Figure 7a,b, we found that the treatment of LX-2 cells with rSjp40 resulted in decreased mRNA levels of classical HSC activation markers such as $\alpha$-smooth muscle actin $(\alpha-S M A)\left(F_{(2,20)}=7.918\right.$, LSD: $\left.p=0.0118\right)$ and COL1A1 $\left(F_{(3,12)}=8.438\right.$, LSD: $\left.p=0.0011\right)$, but in contrast, $\mathrm{rSjp} 90 \alpha$ had no significant effect on the expression of these two components. 
a

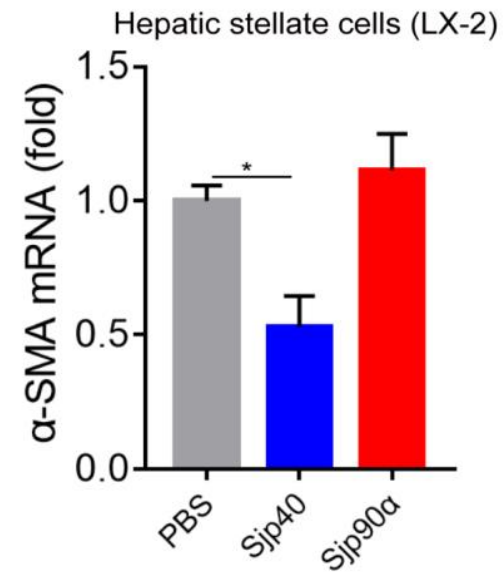

b

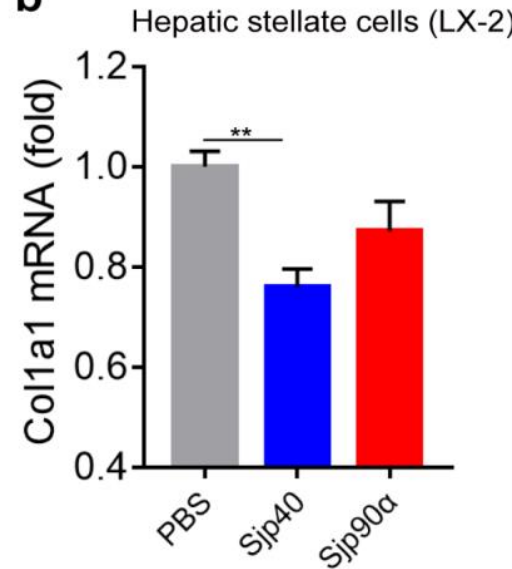

Figure 7. Different effects of rSjp40 and rSjp90 $\alpha$ on $\alpha$-SMA and COL1A1 expression in LX-2 cells. Transcript expression levels of $\alpha$-SMA (a) and COL1A1 (b) in LX-2 cells co-cultured with PBS, rSjp40 and rSjp90 $\alpha$, respectively. $\beta$-actin was used as the internal standard for normalization. Data are expressed as the mean $\pm \operatorname{SEM}\left(n=8\right.$ each group) ${ }^{* *} p<0.01,{ }^{*} p<0.05$, compared with PBS control.

\section{Discussion}

HSPs, such as HSP40, HSP60, HSP70, and HSP90, are known to be widely expressed by parasites and they play critical roles in the activation and regulation of host innate and antigen-specific adaptive immune responses, the study of which might potentially reveal new anti-parasite vaccine candidates [34-37]. In the present study, we cloned two HSPs (Sjp40 and Sjp90 $\alpha$ ) from S. japonicum, expressed them in Escherichia coli (E. coli), and obtained purified soluble recombinant proteins to study their expression and their preliminary characterization. In addition, we report for the first time, an investigation on the roles of Sjp40 and Sjp90 $\alpha$ on the regulation of hepatic immune cells.

Additional features of Sjp40 revealed in this study include its distribution in eggs and adult S. japonicum and its effect on mouse hepatic immune cells and hepatic stellate cells following a previous investigation of its diagnostic potential [10]. Sjp90 $\alpha$ is found abundantly in the excretory-secretory proteome [7] and in the mRNA [13] in adult S. japonicum worms, but no further characterization had been undertaken on this HSP. Accordingly, we isolated Sjp90 $\alpha$ from S. japonicum and used the recombinant protein for more functional exploits. Our immunolocalization analysis showed Sjp $90 \alpha$ was not only expressed throughout the tissues (parenchyma or vitelline cells) of adult worms but was also present in the worm tegument. Given the high homology evident between host HSP90 and Sjp90 $\alpha$, the tegumental location of Sjp90 $\alpha$ in adult S. japonicum raises concerns whether the signaling we observed by immunolocalization is indeed specifically representing the location of Sjp90 $\alpha$ itself rather than host HSp90. Regarding this point, during the immunolocalization procedure, goat serum ( $1 \%$ in blocking buffer) was used to block the worm sections, thereby removing the non-specific background before reacting with primary antibody. In addition, freshly perfused adult worms were washed with perfusion buffer (at least three times) before fixing and the host HSP90 attached to the surface of worms was likely removed. This was reinforced with our observations of negative control worms when normal mouse serum was used as primary antibody (Figure S4), showing host HSP90 was still present in the gut, but there was no signal detectable on the worm surface. We speculate that the location of Sjp90 $\alpha$ on the worm surface of S. japonicum might help the parasite adapt to the host immune microenvironment and aid it in switching from an immune-sensitive to an immune-tolerance state [38]. Previous work showed killing of S. japonicum worms after treatment with the HSP90 inhibitor, geldanamycin, in vitro [39], suggesting Sjp90a is a potential therapeutic target. However, the high identity between Sjp90 and host HSP90 might limit the use of this HSP90 inhibitor.

Both Sjp40 and Sjp90 $\alpha$ were found to be present in the Reynolds' layer within the mature egg, suggesting these proteins are secreted by the miracidium and accumulate between the envelope and 
the eggshell [31]. We confirmed the expression of Sjp40 and Sjp90 $\alpha$ in the egg secretory proteins (ESP), indicating that they are secreted by mature eggs and can interact with surrounding cells. The major immunopathological consequences of $S$. japonicum infection are the egg-induced type 2 immune reaction and the dynamic granulomatous process, which is dependent on the generation of a molecule or molecules attracting eosinophils, neutrophils, macrophages, and other immune cells [40]. Our data show that $\mathrm{rSjp} 40$ was able to enhance the expression of macrophages, dendritic cells, and eosinophilic cells; while stimulation with rSjp90 $\alpha$ primarily increased the numbers of dendritic cells, which may be induced by the non-homologous domain of Sjp $90 \alpha$, given the high identity between Sjp $90 \alpha$ and host HSP90. However, the smaller immune response induced by rSjp90 $\alpha$ implies again that this protein might be associated with a species-specific type of immune evasion to assist the schistosome parasite survive in its definitive hosts, a concept supported by a previous study [7].

It has been reported that human HSP40 can bind to the human androgen receptor (AR) [41], a type of progesterone receptors; these have a diverse range of biological actions including important roles in the development and maintenance of the reproductive and immune systems [42]. In addition, there is evidence indicating HSP90 promotes the interaction of steroid hormone with the glucocorticoid receptor (GR), resulting in maintenance hormone binding activity [43]. However, the precise roles that Sjp40 and Sjp90 $\alpha$ play in the modulation of host immune responses remain unclear. Indeed, whether Sjp40 interacts with host specific proteins or receptors needs determined in future study. Previous work showed human HSP90 $\alpha$ can promote human skin cell migration through CD91 and activate wound healing responses [44]. The high amino acid sequence identity (61\%) between Sjp90 $\alpha$ and host HSP90 suggests the schistosome HSP may function in granuloma wound healing but this also needs to be further addressed.

It is well recognized that the dominant Th1 response is induced in mice at the early stage (at 3-5 weeks post-infection) of a schistosome infection. With the sexual maturation of adult worms in the host and a large number of eggs released by mature females (at 5-6 weeks post-infection), the host immune response shifts from Th1 to a strong Th2/Th17 response [3]. Our ex-vivo data show that rSjp40 might contribute to the dynamic immune response through inducing the Th1, Th2, and Th17 cellular response, whereas rSjp90 $\alpha$ predominantly induced increased Th17 cell response. Previous studies showed that some $\mathrm{CD} 4^{+} \mathrm{T}$ cell populations do not express CD90.2 (CD90.2- ${ }^{-} D 4^{+}$cells), which is highly expressed in gut-associated Peyer's patches [45] and in the germinal centers of spleen and lymph nodes [33]. Our results showed that the unusual $\mathrm{CD} 90.2^{-} \mathrm{CD} 4^{+}$cell subsets response appeared to increase in hepatic immune cells after they had been in vitro stimulated by either rSjp 40 or rSjp90 $\alpha$, suggesting that the growth of these cell subsets may be associated with the process of immune regulation during S. japonicum infection. In addition, we found that the expression of fibrogenic gene markers ( $\alpha$-SMA and COL1A1) was decreased in human HSC after being incubated with rSjp40 but not with rSjp90 $\alpha$. This suggests Sjp40 might play a pivotal role in the suppression of liver fibrosis, whereas Sjp90 $\alpha$ appears to play no part in this process.

\section{Methods}

\subsection{Ethics Statement}

The conduct and procedures involving animal experimentation were approved by the Animal Ethics Committee of QIMR Berghofer Medical Research Institute (project number 288 and ethics ID A0108-054). This study was performed in accordance with the recommendations in the Guide for the Care and Use of Laboratory Animals of the USA National Institutes of Health.

\subsection{Parasites}

S. japonicum adult worms were collected by perfusion of ARC Swiss mice infected percutaneously with 60 cercariae of S. japonicum (Anhui population, mainland China), shed from Oncomelania hupensis snails, which were transported to the QIMR Berghofer Medical Research Institute in Australia. 
Female Swiss mice were percutaneously infected with S. japonicum cercariae. Adult worms were collected from infected mice 6 weeks post infection. Mice were perfused with perfusion buffer [46] to remove worms from mesenteric veins. Eggs were harvested from mouse liver as described [47]. Briefly, livers were minced with scissors and digested in PBS containing $100 \mathrm{mg} / \mathrm{mL}$ Collagenase B (Roche, Mannheim, Germany) and 1\% ( $/ v)$ penicillin/streptomycin (Gibco, Waltham, MA, USA) overnight at $37^{\circ} \mathrm{C}$. The digested eggs were then centrifuged at $500 \times \mathrm{g}$ for $5 \mathrm{~min}$, followed by washing with ice-cold PBS 3 times. Then the eggs were collected by passing through $250 \mu \mathrm{m}$ and $150 \mu \mathrm{m}$ cell strainers, separately, and then purified using a Percoll (GE Healthcare, Buckinghamshire, UK) gradient.

\subsection{Bioinformatic Analysis}

BLAST of Sjp40 (Sjp_0021240) and Sjp90 $\alpha$ (Sjp_0044660) was performed in the Wormbase (https://parasite.wormbase.org). The BioEdit software was used for multiple sequence alignments. The motif domains of Sjp40 and Sjp90 $\alpha$ were analyzed using the ScanProsite of ExPASy analysis tools (https://prosite.expasy.org). Sjp40 and Sjp90 $\alpha$ homologous sequences were analyzed by the neighbor-joining method for phylogenetic analysis and the tree was plotted using MEGA-X software [48]. The demonstration of the Sjp40 and Sjp90 $\alpha$ tertiary structure was created by online SWISS-MODEL (https://swissmodel.expasy.org) [49]. ATP-binding residues for Sjp90 were predicted by NsitePred (http://biomine.cs.vcu.edu/servers/NsitePred/) [50].

\subsection{Preparation of Soluble Egg Antigen and ESP}

Soluble egg antigen (SEA) of S. japonicum were prepared as described [47] with some modification. Briefly, eggs were suspended in $1 \times$ PBS plus protease inhibitor cocktail (Sigma-Aldrich, Milwaukee, WI, USA) and homogenized using a Precellys Homogeniser (Stretton Scientific, Derbyshire, UK) at $5500 \mathrm{rpm}$ for $30 \mathrm{~s}$ at $4{ }^{\circ} \mathrm{C}$. Following centrifugation at $16,000 \times g$ for $1 \mathrm{~h}$, the supernatant (SEA) was collected. Residual endotoxin in the SEA extracts was determined using a Pierce LAL Chromogenic Endotoxin Quantitation Kit (Thermo Scientific, Rockford, USA) according to the manufacturer's instructions.

For the preparation of excretory secretory protein (ESP) antigens from eggs, approximately 30,000 eggs/well were cultured in a 24-well plate with $1 \mathrm{~mL}$ RPMI1640 and $1 \%(v / v)$ penicillin/streptomycin at $37^{\circ} \mathrm{C}$. Culture supernatant was collected twice with a three-day interval and replaced by $1 \mathrm{~mL}$ fresh media. The mixture of supernatants was then filtered through a $20 \mu \mathrm{m}$ strainer and concentrated using a 3-5 KDa MW filter.

\subsection{Escherichia Coli Protein Expression}

A 1065 bp fragment of cDNA encoding Sjp40 and a 780 bp fragment of cDNA encoding Sjp $90 \alpha$ were amplified by PCR and inserted into the pET28b vector (Invitrogen, Carlsbad, CA, USA). E. coli BL21 (DE3) cells (Invitrogen) were transformed with the reconstructed plasmids for protein expression as described [51]. The expressed rSjp40 and rSjp90 $\alpha$ proteins were purified from E. coli lysates using Ni-NTA affinity chromatography (GE Health Life Science, Pittsburgh, PA, USA). Given previous studies showing the $6 \times$ His tag did not stimulate any immunogenic activity [52-55], the tag was not removed after purification of $\mathrm{rSjp} 40$ and $\mathrm{rSjp} 90 \alpha$. However residual endotoxin was removed from both recombinant proteins as described [51] and Endotoxin (E. coli) Standards kits (Lonza, Basel, Switzerland) were used subsequently to confirm there was no Endotoxin contamination in either protein.

\subsection{Preparation of Sjp40 and Sjp90 $\alpha$ Antibody}

Sjp40 and Sjp90 $\alpha$ antiserum were prepared in Swiss mice. Recombinant Sjp40 or Sjp90 $\alpha$ were formulated with either Complete Freund's Adjuvant (Sigma-Aldrich, Castle Hill, Australia) (primary injection) or Incomplete Freund's Adjuvant (two boosts at two weekly intervals) (Sigma-Aldrich) and the preparations were subcutaneously injected into the mice. Mouse bloods were collected 2 weeks after the last injection using cardiac puncture and sera obtained. Antibody titres were determined 
using an enzyme-linked immunosorbent assay (ELISA) against rSjp40 $(1: 128,000)$ or rSjp90 $\alpha(1: 128,000)$ as described [56].

\subsubsection{Western Blotting}

For Western blot analysis, equivalent amounts of the Sjp40 and Sjp $90 \alpha$ recombinant proteins $(\sim 10 \mu \mathrm{g})$ or protein $(\sim 200 \mu \mathrm{g})$ from SEA or ESP were loaded into each lane for separation by SDS-PAGE and electrophoresed proteins were then transferred onto Immu-Blot ${ }^{\circledR}$ PVDF membranes (Bio-Rad, Hercules, CA, USA). After blocking in Odyssey Blocking Buffer for $1 \mathrm{~h}$ at room temperature, membranes were incubated at $4{ }^{\circ} \mathrm{C}$ overnight with primary antibodies: mouse anti-rSjp40 or mouse anti-rSjp $90 \alpha$, respectively. After washing with PBS plus $0.1 \%$ Tween 20 with gentle shaking, the membranes were incubated at room temperature for $1 \mathrm{~h}$ with IRDye ${ }^{\circledR}$ secondary antibody (1:20,000 dilution) in Odyssey Blocking Buffer plus 0.1-0.2\% Tween 20. After washing, the blots were developed using the Odyssey Imaging System.

\subsubsection{Immunohistochemistry}

Liver tissue from mice infected with S. japonicum or adult worms perfused from infected mice with perfusion buffer $(0.85 \%(w / v) \mathrm{NaCl}$ plus $1 \%(w / v)$ trisodium citrate) were fixed in $10 \%$ formalin, embedded in paraffin and sectioned at $3 \mu \mathrm{m}$. Following antigen retrieval by boiling in $0.01 \mathrm{M}$ sodium citrate, $\mathrm{pH} \mathrm{6,} \mathrm{for} 20 \mathrm{~min}$ in a water bath, endogenous peroxidase activity was blocked by incubation with $3 \%(v / v) \mathrm{H}_{2} \mathrm{O}_{2}$ for $20 \mathrm{~min}$ at room temperature. Slides were washed three times with PBS and blocked with 5\% bovine serum albumin and 1\% (w/v) goat serum in tris buffered saline (TBS) for $30 \mathrm{~min}$ at room temperature. Tissue sections were then probed with 1:100 diluted mouse anti-rSjp40 or rSjp $90 \alpha$ sera for $1 \mathrm{~h}$ at $37^{\circ} \mathrm{C}$ (normal mouse serum was used as negative control). Slides were then washed three times with $1 \times$ PBS, and HRP conjugated secondary antibody (Sigma) was added as secondary antibody at dilution of 1:1000 and incubated for $10 \mathrm{~min}$ at room temperature. Sections were examined with an Aperio Scanscope XT scanner (Aperio Technologies, Vista, CA, USA) and analyzed using ImageScope software (Aperio, ImageScope version 10.2.1.2315).

To confirm the integrity of the HRP labelling of Sjp40 and Sjp $90 \alpha$, we replaced the HRP conjugated secondary antibody with Alexa-Fluor 647 conjugated antibody for the immunolocalisation analysis. Briefly, the fixed liver tissue or adult worm sections were treated with Revealt A solution (Biocare Medical, Concord, MA, USA) at $120^{\circ} \mathrm{C}$ for $5 \mathrm{~min}$ for antigen retrieval. After the non-specific binding sites were blocked with $1 \%(w / v)$ bovine serum albumin and $1 \%(w / v)$ goat serum in TBS for $60 \mathrm{~min}$ at $4{ }^{\circ} \mathrm{C}$, the liver tissue or worm sections were stained with mouse anti-mouse Sjp40 or Sjp90 $\alpha$ overnight at $4^{\circ} \mathrm{C}$ as described [27] (normal mouse sera were used as negative control). After staining, excess antibody was removed by four washing steps with TBST (0.05\% (v/v) Tween 20 in TBS). Then the liver tissue or sections were incubated with Alexa-Fluor 647 goat anti-mouse IgG (1:500) (Invitrogen, Carlsbad, CA, USA) at $37{ }^{\circ} \mathrm{C}$ for $1 \mathrm{~h}$. Diamidino-2-phenylindole (DAPI) gold (Invitrogen) was used to stain for nuclei and the samples were analyzed using a Zeiss 780 NLO laser (Zeiss, Oberkochen, Germany).

\subsubsection{Quantitative RT-PCR (qRT-PCR)}

Total RNA was extracted from human hepatic stellate or different life cycle stages of S. mansoni (including female worms, male worms, schistosomula, eggs and cercariae; miracidia was not included due to limited materials) using RNeasy Mini Kits (Qiagen, Hilden, Germany). First strand cDNA was synthesized using a Sensiscript Reverse Transcription for First strand cDNA synthesis Kit (Qiagen) and was subsequently used as template in qPCR to determine the expression levels of Sjp40 and Sjp90 $\alpha$ in different life cycle stages and the $\alpha$-SMA and COL1A1 expression levels in hepatic stellate cells. S. japonicum PSMD4 (26S proteasome non-ATPase regulatory subunit 4) [27] or the human housekeeping gene $\beta$-actin [57] was used as the reference gene. Real-time PCR was performed using Power Syber Green PCR Master Mix (Applied Biosystems, Foster City, CA, USA) and data were processed using 
Rotor Gene 6000 series software (Corbett Life Science, Australia). The cycling parameters were as follows: $95^{\circ} \mathrm{C}$ for $3 \mathrm{~min} ; 30$ cycles of $95^{\circ} \mathrm{C}$ for $30 \mathrm{~s}$ and $54^{\circ} \mathrm{C}$ for $30 \mathrm{~s}$, and $70{ }^{\circ} \mathrm{C}$ for $5 \mathrm{~min}$. Relative expression levels were calculated using the comparative CT method $\left(2^{-\Delta \Delta C t}\right)$ [58]. Then, mRNA levels of each $S$. japonicum stage were normalized to the data obtained with female worms, based on their suitably expressed CT values. The sequences of primers used in this analysis are shown in Supplementary Table S1.

\subsection{Preparation of Liver Non-Parenchymal Cells (NPC)}

Liver nonparenchymal cells (NPCs) were isolated following an established method with some modifications [59]. Briefly, five livers collected from mice at 6-week post $S$. japonicum infection were cut into small pieces and digested in $20 \mathrm{mg}$ Collagenase $\mathrm{B}$ at $37^{\circ} \mathrm{C}$ for $45 \mathrm{~min}$. The digested liver tissue was then mashed through a $100 \mu \mathrm{m}$ filter, followed by centrifugation at $400 \mathrm{~g}$ for $6 \mathrm{~min}$. The cell pellets were purified using Percoll gradients (GE Healthcare) by centrifuging at $690 \times g$ for $12 \mathrm{~min}$ at room temperature. After discarding the upper layers carefully, the cell pellets were collected and resuspended in red cell lysis buffer (Sigma-Aldrich) and then washed in $10 \mathrm{~mL}$ complete RPMI1640 (Gibco, Grand Island, NY, USA) containing 10\% (v/v) FBS (Gibco) and 1\% (v/v) penicillin/streptomycin (Gibco). Then, the single cell suspension was collected through the Pre-Separation Filters (20 $\mu \mathrm{m}$, Miltenyi Biotec, Bergisch Gladbach, Germany) for further study.

\subsubsection{Flow Cytometry}

For Th1/Th2/Th17 cells analysis, $2 \times 10^{6}$ of single cell suspensions were cultured in complete RPMI 1640 medium and stimulated with rSjp40, rSjp90 $\alpha$, or SEA, at $20 \mu \mathrm{g} / \mathrm{mL}$ for $44 \mathrm{~h}$; then the cells were mixed with $25 \mathrm{ng} / \mathrm{mL}$ PMA (Sigma) and $1 \mu \mathrm{g} / \mathrm{mL}$ ionomycin (Sigma) in the presence of $0.66 \mu \mathrm{L} / \mathrm{mL}$ Golgistop (BD Bioscience, Melbourne, Australia) at $37^{\circ} \mathrm{C}$ in $5 \% \mathrm{CO}_{2}$ for $4 \mathrm{~h}$. Cells were blocked with $\mathrm{FC}_{\mathrm{C}}$ receptor (BD Bioscience) and stained with the Live/Dead-Horizon stain (Thermo Fisher Scientific, 1:1000 dilution) for $15 \mathrm{~min}$, surface-stained with CD90.2 (Thy1.2)-PEcy7 and CD4-BV785 antibodies (BD Bioscience, 1:200 dilution) for $30 \mathrm{~min}$, then cells were fixed and permeabilized with BD Cytofix/Cytoperm buffer (BD Bioscience) as per the manufacturer's protocol and intracellularly stained with IFN- $\gamma$-Percp/cy5.5, IL-4-PE-CF594, and IL-17A-AF647 (BD Bioscience, all 1:100 dilution) for $30 \mathrm{~min}$.

For Treg cells analysis, $2 \times 10^{6}$ of single cell suspensions were incubated with rSjp40 $(20 \mu \mathrm{g} / \mathrm{mL})$, rSjp90 $\alpha(20 \mu \mathrm{g} / \mathrm{mL})$, or SEA $(20 \mu \mathrm{g} / \mathrm{mL})$ for $48 \mathrm{~h}$, followed by staining with the Live/Dead-Horizon stain (Thermo Fisher Scientific, 1:1000 dilution) for $15 \mathrm{~min}$, and then surface-stained with CD90.2 (Thy-1.2)-PEcy7 and CD4-BV785 (BD Bioscience, 1:200 dilution) for $30 \mathrm{~min}$. Then, cells were then fixed and permeabilized with fixation/permeabilization buffers (BD Bioscience) for $50 \mathrm{~min}$ and then blocked with Fc receptor (BD Bioscience). Finally, cells were stained with PE-conjugated anti-Foxp3 antibodies (BD Bioscience, 1:200 dilution) for $30 \mathrm{~min}$.

For other hepatic immune cells analysis, $2 \times 10^{6}$ of single cell suspensions were stimulated with $\mathrm{rSjp} 40, \mathrm{rSjp} 90 \alpha$, or SEA, at $20 \mu \mathrm{g} / \mathrm{mL}$ for $48 \mathrm{~h}$ and stained with the Live/Dead-Horizon stain (Thermo Fisher Scientific) for $15 \mathrm{~min}$ and then surface-stained with Gr-1-AF700, CD11c-APC/cy7, F4/80-BV421, and Siglecf-BV605 (all from BD Bioscience) for $30 \mathrm{~min}$. All the stained cells were collected using Fortessa $4 \mathrm{~A}$ and FACS Diva software (BD Bioscience). Flow cytometry analysis was performed using FlowJo version 10 software (TreeStar, Ashland, OR, USA).

\subsubsection{LX-2 Human Hepatic Stellate Cell Culture and Treatment}

A total of $5 \times 10^{5}$ of LX-2 cells/well were cultured in six-well plates containing DMEM supplemented with $10 \%(v / v)$ FBS and $1 \%(v / v)$ penicillin/streptomycin, at $37^{\circ} \mathrm{C}$ in a humidified atmosphere containing $5 \% \mathrm{CO}_{2}$. LX-2 cells were stimulated with PBS, rSjp40 $(20 \mu \mathrm{g} / \mathrm{mL})$ or $\mathrm{rSjp} 90(20 \mu \mathrm{g} / \mathrm{mL})$ for $48 \mathrm{~h}$, respectively; then the cells were collected by centrifugation at $500 \mathrm{~g}$ for $5 \mathrm{~min}$. Total RNA was extracted 
from these cells and used as template to synthesize cDNA which was used for RT-PCR analysis to determine the expression level of fibrosis-related genes ( $\alpha$-SMA and COL1A1) as described above.

\subsection{Statistical Analysis}

All analyses were carried out with GraphPad software (Version 7.02). Data are shown as means \pm SEM. The significance of the difference between two groups was determined using Student's $\mathrm{t}$ test. Multiple comparisons were performed by one-way ANOVA, followed by LSD post-testing for comparisons between two groups. $F$ values and $p$ values were calculated by GraphPad software. $p$ values $<0.05$ were considered significant. The $F_{(\mathrm{dfn}, \mathrm{dfd})}$ distribution has two parameters: Degrees of freedom numerator (dfn) and degree of freedom denominator (dfd).

$\mathrm{Dfn}=$ the number of groups $-1 ; \mathrm{dfd}=$ the total number of subjects in the experiment- $\mathrm{dfn}$.

\section{Conclusions}

To better understand the roles of HSPs in schistosomes, we isolated and characterized two HSPs, Sjp40 and Sjp90 $\alpha$, from S. japonicum. Immunolocalisation of these proteins in eggs and in adult S. japonicum and their contribution in the development of hepatic immunopathology, potentially provides new insights into the disease of schistosomiasis. In addition, in contrast to Sjp40, Sjp $90 \alpha$ being located on the tegument of adult $S$. japonicum may play an important role in helping the parasite adapt to the host immune microenvironment, as it switches from an immune-sensitive to an immune-tolerance state.

Supplementary Materials: Supplementary materials can be found at http://www.mdpi.com/1422-0067/21/11/ 4034/s1. Figure S1: Conserved functional domains of Sjp40; Figure S2: Conserved functional domains of Sjp $90 \alpha$; Figure S3: The representative figure about the purified eggs; Figure S4: Distribution of Sjp40 and Sjp90 $\alpha$ in adult S. japonicum by Immunohistochemistry. Table S1: The sequences of primers.

Author Contributions: Conceived and designed the experiments: H.Y. and D.P.M. Performed the experiments: Z.X., C.L. and X.D. Analyzed the data: Z.X. and H.Y. Contributed reagents/materials/analysis tools: Z.X., C.L., X.D., M.J. and W.H. Wrote the paper: Z.X., H.Y. and D.P.M. All authors have read and agreed to the published version of the manuscript.

Funding: This work received support from an Australian Infectious Disease Research Centre Seed Grant, a Program Grant from the National Health and Medical Research Council of Australia (APP 1037304) and the National Natural Science Foundation of China (Project no. 81702023).

Acknowledgments: We are very thankful to Mary Duke (QIMR Berghofer Medical Research Institute) for her support by performing all the mouse perfusions and the maintenance of the parasite life cycle. We also thank Wei Hu at Fudan University for providing the gene chip data for identifying potentially important molecules in S. japonicum soluble egg antigen. We thank the staff at the QIMR-Berghofer including the animal facility, Flow Cytometry (Grace Chojnowski, Amanda Stanley, Lucie Leveque-ElMouttie, and Christopher McRandle), Microscope Facility (Tam Hong Nguyen, Nigel Waterhouse), and the Immunology in Cancer and Infection Laboratory (Juming Yan).

Conflicts of Interest: The authors declare that they have no competing financial interests. The funders had no role in the design of the study; in the collection, analyses, or interpretation of data; in the writing of the manuscript, or in the decision to publish the results.

\section{References}

1. Steinmann, P.; Keiser, J.; Bos, R.; Tanner, M.; Utzinger, J. Schistosomiasis and water resources development: Systematic review, meta-analysis, and estimates of people at risk. Lancet Infect. Dis. 2006, 6, 411-425. [CrossRef]

2. McManus, D.P.; Gray, D.J.; Ross, A.G.; Williams, G.M.; He, H.B.; Li, Y.S. Schistosomiasis research in the dongting lake region and its impact on local and national treatment and control in China. PLoS Negl. Trop. Dis. 2011, 5, e1053. [CrossRef] [PubMed]

3. Pearce, E.J.; MacDonald, A.S. The immunobiology of schistosomiasis. Nat. Rev. Immunol. 2002, 2, $499-511$. [CrossRef] [PubMed]

4. Coakley, G.; Wright, M.D.; Borger, J.G. Schistosoma mansoni-Derived Lipids in Extracellular Vesicles: Potential Agonists for Eosinophillic Tissue Repair. Front. Immunol. 2019, 10, 1010. [CrossRef] 
5. van Eden, W.; Jansen, M.A.A.; Ludwig, I.; van Kooten, P.; van der Zee, R.; Broere, F. The Enigma of Heat Shock Proteins in Immune Tolerance. Front. Immunol. 2017, 8, 1599. [CrossRef]

6. Pockley, A.G. Heat shock proteins as regulators of the immune response. Lancet 2003, 362, 469-476. [CrossRef]

7. Liu, F.; Cui, S.J.; Hu, W.; Feng, Z.; Wang, Z.Q.; Han, Z.G. Excretory/secretory proteome of the adult developmental stage of human blood fluke, Schistosoma japonicum. Mol. Cell. Proteom. MCP 2009, 8, 1236-1251. [CrossRef]

8. Hong, Y.; Peng, J.; Jiang, W.; Fu, Z.; Liu, J.; Shi, Y.; Li, X.; Lin, J. Proteomic analysis of schistosoma japonicum schistosomulum proteins that are differentially expressed among hosts differing in their susceptibility to the infection. Mol. Cell. Proteom. MCP 2011, 10, M110 006098. [CrossRef]

9. Sun, X.; Zhang, L.; Wang, J.; Chen, J.; Zhu, D.; Shen, P.; He, X.; Pan, J.; Peng, W.; Duan, Y. Schistosoma japonicum protein SjP40 inhibits TGF-beta1-induced activation of hepatic stellate cells. Parasitol. Res. 2015, 114, 4251-4257. [CrossRef]

10. Zhou, X.H.; Wu, J.Y.; Huang, X.Q.; Kunnon, S.P.; Zhu, X.Q.; Chen, X.G. Identification and characterization of Schistosoma japonicum Sjp40, a potential antigen candidate for the early diagnosis of schistosomiasis. Diagn. Microbiol. Infect. Dis. 2010, 67, 337-345. [CrossRef]

11. Li, S.S.; Xu, X.T.; Liu, W.; Xu, Z.P.; Zhang, W.W.; Li, Y.; Dong, X.X.; Yang, X.W.; Liu, F.; Wang, Y.Z.; et al. [Effects of Schistosoma japonicum heat-shock protein 40 on macrophage activation]. Zhongguo xue xi chong bing fang zhi za zhi = Chin. J. Schistosomiasis Control 2012, 24, 137, 141-149.

12. Ren, J.; Hu, L.; Yang, J.; Yang, L.; Gao, F.; Lu, P.; Fan, M.; Zhu, Y.; Liu, J.; Chen, L.; et al. Novel T-cell epitopes on Schistosoma japonicum SjP40 protein and their preventive effect on allergic asthma in mice. Eur. J. Immunol. 2016, 46, 1203-1213. [CrossRef] [PubMed]

13. Hu, W.; Yan, Q.; Shen, D.K.; Liu, F.; Zhu, Z.D.; Song, H.D.; Xu, X.R.; Wang, Z.J.; Rong, Y.P.; Zeng, L.C.; et al. Evolutionary and biomedical implications of a Schistosoma japonicum complementary DNA resource. Nat. Genet. 2003, 35, 139-147. [CrossRef] [PubMed]

14. Yang, L.L.; Lv, Z.Y.; Hu, S.M.; He, S.J.; Li, Z.Y.; Zhang, S.M.; Zheng, H.Q.; Li, M.T.; Yu, X.B.; Fung, M.C.; et al. Schistosoma japonicum: Proteomics analysis of differentially expressed proteins from ultraviolet-attenuated cercariae compared to normal cercariae. Parasitol. Res. 2009, 105, 237-248. [CrossRef]

15. Kusel, J.R.; Wales, A.; Vieira, L.; Wu, K.Y. Effects of irradiation and tunicamycin on the surface glycoproteins of Schistosoma mansoni. Memorias Inst. Oswaldo Cruz 1989, 84 (Suppl. 1), 199-208. [CrossRef]

16. Chen, J.H.; Zhang, T.; Ju, C.; Xu, B.; Lu, Y.; Mo, X.J.; Chen, S.B.; Fan, Y.T.; Hu, W.; Zhou, X.N. An integrated immunoproteomics and bioinformatics approach for the analysis of Schistosoma japonicum tegument proteins. J. Proteom. 2014, 98, 289-299. [CrossRef]

17. Arnold, K.; Bordoli, L.; Kopp, J.; Schwede, T. The SWISS-MODEL workspace: A web-based environment for protein structure homology modelling. Bioinformatics 2006, 22, 195-201. [CrossRef]

18. Towler, D.A.; Gordon, J.I.; Adams, S.P.; Glaser, L. The biology and enzymology of eukaryotic protein acylation. Annu. Rev. Biochem. 1988, 57, 69-99. [CrossRef]

19. Kishimoto, A.; Nishiyama, K.; Nakanishi, H.; Uratsuji, Y.; Nomura, H.; Takeyama, Y.; Nishizuka, Y. Studies on the phosphorylation of myelin basic protein by protein kinase $C$ and adenosine 3':5'-monophosphate-dependent protein kinase. J. Biol. Chem. 1985, 260, 12492-12499.

20. Pinna, L.A. Casein kinase 2: An 'eminence grise' in cellular regulation? Biochim. Biophys. Acta 1990, 1054, 267-284. [CrossRef]

21. Branza-Nichita, N.; Negroiu, G.; Petrescu, A.J.; Garman, E.F.; Platt, F.M.; Wormald, M.R.; Dwek, R.A.; Petrescu, S.M. Mutations at critical N-glycosylation sites reduce tyrosinase activity by altering folding and quality control. J. Biol. Chem. 2000, 275, 8169-8175. [CrossRef] [PubMed]

22. Glass, D.B.; Smith, S.B. Phosphorylation by cyclic GMP-dependent protein kinase of a synthetic peptide corresponding to the autophosphorylation site in the enzyme. J. Biol. Chem. 1983, 258, 14797-14803. [PubMed]

23. Feramisco, J.R.; Glass, D.B.; Krebs, E.G. Optimal spatial requirements for the location of basic residues in peptide substrates for the cyclic AMP-dependent protein kinase. J. Biol. Chem. 1980, 255, 4240-4245.

24. Hubbard, S.R.; Till, J.H. Protein tyrosine kinase structure and function. Annu. Rev. Biochem. 2000, 69, 373-398. [CrossRef] [PubMed]

25. Prodromou, C.; Pearl, L.H. Structure and functional relationships of Hsp90. Curr. Cancer Drug Targets 2003, 3, 301-323. [CrossRef] [PubMed] 
26. Stechmann, A.; Cavalier-Smith, T. Phylogenetic analysis of eukaryotes using heat-shock protein Hsp90. J. Mol. Evol. 2003, 57, 408-419. [CrossRef]

27. Du, X.; Jones, M.K.; Nawaratna, S.S.K.; Ranasinghe, S.; Xiong, C.; Cai, P.; McManus, D.P.; You, H. Gene Expression in Developmental Stages of Schistosoma japonicum Provides Further Insight into the Importance of the Schistosome Insulin-Like Peptide. Int. J. Mol. Sci. 2019, 20, 1565. [CrossRef] [PubMed]

28. Liu, S.; Cai, P.; Hou, N.; Piao, X.; Wang, H.; Hung, T.; Chen, Q. Genome-wide identification and characterization of a panel of house-keeping genes in Schistosoma japonicum. Mol. Biochem. Parasitol. 2012, 182, 75-82. [CrossRef]

29. Cai, P.; Piao, X.; Hou, N.; Liu, S.; Wang, H.; Chen, Q. Identification and characterization of argonaute protein, Ago2 and its associated small RNAs in Schistosoma japonicum. PLoS Negl. Trop. Dis. 2012, 6, e1745. [CrossRef]

30. Cai, P.; Liu, S.; Piao, X.; Hou, N.; Gobert, G.N.; McManus, D.P.; Chen, Q. Comprehensive Transcriptome Analysis of Sex-Biased Expressed Genes Reveals Discrete Biological and Physiological Features of Male and Female Schistosoma japonicum. PLoS Negl. Trop. Dis. 2016, 10, e0004684. [CrossRef]

31. Ashton, P.D.; Harrop, R.; Shah, B.; Wilson, R.A. The schistosome egg: Development and secretions. Parasitology 2001, 122 Pt 3, 329-338. [CrossRef]

32. Larsen, M.R.; Trelle, M.B.; Thingholm, T.E.; Jensen, O.N. Analysis of posttranslational modifications of proteins by tandem mass spectrometry. BioTechniques 2006, 40, 790-798. [CrossRef] [PubMed]

33. Zheng, B.; Han, S.; Kelsoe, G. T helper cells in murine germinal centers are antigen-specific emigrants that downregulate Thy-1. J. Exp. Med. 1996, 184, 1083-1091. [CrossRef] [PubMed]

34. Brandau, S.; Dresel, A.; Clos, J. High constitutive levels of heat-shock proteins in human-pathogenic parasites of the genus Leishmania. Biochem. J. 1995, 310 Pt 1, 225-232. [CrossRef]

35. Maresca, B.; Kobayashi, G.S. Hsp70 in parasites: As an inducible protective protein and as an antigen. Experientia 1994, 50, 1067-1074. [CrossRef] [PubMed]

36. Younis, A.E.; Geisinger, F.; Ajonina-Ekoti, I.; Soblik, H.; Steen, H.; Mitreva, M.; Erttmann, K.D.; Perbandt, M.; Liebau, E.; Brattig, N.W. Stage-specific excretory-secretory small heat shock proteins from the parasitic nematode Strongyloides ratti-putative links to host's intestinal mucosal defense system. FEBS J. 2011, 278, 3319-3336. [CrossRef] [PubMed]

37. Hisaeda, H.; Himeno, K. The role of host-derived heat-shock protein in immunity against Toxoplasma gondii infection. Parasitol. Today 1997, 13, 465-468. [CrossRef]

38. Fonseca, C.T.; Braz Figueiredo Carvalho, G.; Carvalho Alves, C.; de Melo, T.T. Schistosoma tegument proteins in vaccine and diagnosis development: An update. J. Parasitol. Res. 2012, 2012, 541268. [CrossRef]

39. Wenkert, D.; Ramirez, B.; Shen, Y.; Kron, M.A. In Vitro Activity of Geldanamycin Derivatives against Schistosoma japonicum and Brugia malayi. J. Parasitol. Res. 2010, 2010, 716498. [CrossRef]

40. Etewa, S.E.; Hegab, M.H.A.; Metwally, A.S.; Abd Allah, S.H.; Shalaby, S.M.; El-Shal, A.S.; Baredy, M.; El Shafey, M.A.; Moawad, H.S.F. Murine hepatocytes DNA changes as an assessment of the immunogenicity of potential anti-schistosomal vaccines experimentally. J. Parasit. Dis. Off. Organ Indian Soc. Parasitol. 2017, 41, 219-229. [CrossRef]

41. Fliss, A.E.; Rao, J.; Melville, M.W.; Cheetham, M.E.; Caplan, A.J. Domain requirements of DnaJ-like (Hsp40) molecular chaperones in the activation of a steroid hormone receptor. J. Biol. Chem. 1999, 274, 34045-34052. [CrossRef] [PubMed]

42. Chang, C.; Lee, S.O.; Wang, R.S.; Yeh, S.; Chang, T.M. Androgen receptor (AR) physiological roles in male and female reproductive systems: Lessons learned from AR-knockout mice lacking AR in selective cells. Biol. Reprod. 2013, 89, 21. [CrossRef] [PubMed]

43. Kosano, H.; Stensgard, B.; Charlesworth, M.C.; McMahon, N.; Toft, D. The assembly of progesterone receptor-hsp90 complexes using purified proteins. J. Biol. Chem. 1998, 273, 32973-32979. [CrossRef] [PubMed]

44. Cheng, C.F.; Fan, J.; Fedesco, M.; Guan, S.; Li, Y.; Bandyopadhyay, B.; Bright, A.M.; Yerushalmi, D.; Liang, M.; Chen, M.; et al. Transforming growth factor alpha (TGFalpha)-stimulated secretion of HSP90alpha: Using the receptor LRP-1/CD91 to promote human skin cell migration against a TGFbeta-rich environment during wound healing. Mol. Cell. Biol. 2008, 28, 3344-3358. [CrossRef] [PubMed]

45. Harriman, G.R.; Lycke, N.Y.; Elwood, L.J.; Strober, W. T lymphocytes that express CD4 and the alpha beta-T cell receptor but lack Thy-1. Preferential localization in Peyer's patches. J. Immunol. 1990, 145, 2406-2414. 
46. You, H.; McManus, D.P.; Hu, W.; Smout, M.J.; Brindley, P.J.; Gobert, G.N. Transcriptional responses of in vivo praziquantel exposure in schistosomes identifies a functional role for calcium signalling pathway member CamKII. PLoS Pathog. 2013, 9, e1003254. [CrossRef]

47. Dalton, J.P.; Day, S.R.; Drew, A.C.; Brindley, P.J. A method for the isolation of schistosome eggs and miracidia free of contaminating host tissues. Parasitology 1997, 115 Pt 1, 29-32. [CrossRef]

48. Kumar, S.; Stecher, G.; Li, M.; Knyaz, C.; Tamura, K. MEGA X: Molecular Evolutionary Genetics Analysis across Computing Platforms. Mol. Biol. Evol. 2018, 35, 1547-1549. [CrossRef]

49. Schwede, T.; Kopp, J.; Guex, N.; Peitsch, M.C. SWISS-MODEL: An automated protein homology-modeling server. Nucleic Acids Res. 2003, 31, 3381-3385. [CrossRef]

50. Chen, K.; Mizianty, M.J.; Kurgan, L. Prediction and analysis of nucleotide-binding residues using sequence and sequence-derived structural descriptors. Bioinformatics 2012, 28, 331-341. [CrossRef]

51. You, H.; Gobert, G.N.; Duke, M.G.; Zhang, W.; Li, Y.; Jones, M.K.; McManus, D.P. The insulin receptor is a transmission blocking veterinary vaccine target for zoonotic Schistosoma japonicum. Int. J. Parasitol. 2012, 42, 801-807. [CrossRef] [PubMed]

52. Freire, T.; Lo-Man, R.; Bay, S.; Leclerc, C. Tn glycosylation of the MUC6 protein modulates its immunogenicity and promotes the induction of Th17-biased T cell responses. J. Biol. Chemi. 2011, 286, 7797-7811. [CrossRef] [PubMed]

53. Zhao, X.; Li, G.; Liang, S. Several affinity tags commonly used in chromatographic purification. J. Anal. Methods Chem. 2013, 2013, 581093. [CrossRef] [PubMed]

54. Loughran, S.T.; Walls, D. Purification of poly-histidine-tagged proteins. Methods Mol. Biol. 2011, 681, 311-335. [PubMed]

55. Ghose, C.; Eugenis, I.; Sun, X.; Edwards, A.N.; McBride, S.M.; Pride, D.T.; Kelly, C.P.; Ho, D.D. Immunogenicity and protective efficacy of recombinant Clostridium difficile flagellar protein FliC. Emerg. Micro. Infect. 2016, 5, e8. [CrossRef]

56. You, H.; Gobert, G.N.; Du, X.; Pali, G.; Cai, P.; Jones, M.K.; McManus, D.P. Functional characterisation of Schistosoma japonicum acetylcholinesterase. Parasit. Vectors 2016, 9, 328. [CrossRef]

57. Liu, J.; Kong, D.; Qiu, J.; Xie, Y.; Lu, Z.; Zhou, C.; Liu, X.; Zhang, R.; Wang, Y. Praziquantel ameliorates CCl4 -induced liver fibrosis in mice by inhibiting TGF-beta/Smad signalling via up-regulating Smad7 in hepatic stellate cells. Br. J. pharmacol. 2019, 176, 4666-4680. [CrossRef]

58. Rao, X.; Huang, X.; Zhou, Z.; Lin, X. An improvement of the 2^(-delta delta CT) method for quantitative real-time polymerase chain reaction data analysis. Biostat. Bioinform. Biomath. 2013, 3, 71-85.

59. Holt, M.P.; Cheng, L.; Ju, C. Identification and characterization of infiltrating macrophages in acetaminophen-induced liver injury. J. Leukoc. Biol. 2008, 84, 1410-1421. [CrossRef] 